\title{
Kirkeeje i Bjolderup sogn i 1443
}

\section{Af Hans Vald. Gregersen.}

Bjolderup præstearkiv indeholder vel nok den ældste fortegnelse over kirke- og præstejord, som er overleveret fra nogen nordslesvigsk landsbykirke, idet den går helt tilbage til 1443, altså næsten et århundrede før reformationen. Som man kunne vente det, er den affattet på latin og giver beliggenheden og størrelsen af de spredt liggende jordstykker, der på den tid stod til kirkens og præstens rådighed.

Ganske modsat, hvad der andre steder er tilfældet, havde den Bjolderup præst ikke noget bol med ottingstal i en bymark. Det er derfor ikke alene i kraft af dets alder, at der tilkommer aktstykket en vis interesse, men også fordi det er et vidnesbyrd om, at de særegne forhold omkring Bjolderup kirke rækker meget langt tilbage. I ældre tid lå Bjolderup kirke aldeles ensomt $\mathbf{i}$ Perbøl mark klods op ad Bolderslev bymarks vestligste udkant, hvor for øvrigt præstegården ligger, adskilt fra kirken ved en bæk, som danner skellet mellem Bolderslevs og Perbøls jordtilliggende. Så langt man kan spore tilbage, har stednavnet Bjolderup kun refereret sig til kirken, skønt endelsen -thorp i høj grad kunne tyde på, at der oprindeligt her har ligget en udflytterby, et torp.

Som følge af disse forhold måtte præsten i Bjolderup tage til takke med de $\mathrm{i}$ jordlisten nævnte spredtliggende jordstykker, hvis beliggenhed man muligvis netop i 1443 har onsket at lade de 24 sognemænd fæstne til papiret, fordi Erik af Pommerns kampe med holstenerne $\mathrm{i}$ de forudgående urolige årtier havde 
vendt op og ned på mangt og meget $\mathrm{i}$ landsognene vest for Åbenrån).

\section{Jordlisten har følgende ordlyd:}

Anno Dni MCCCCXLIII fuerunt congregati XXIIII parochiani in Ecclesia Bjolderup ad concordandum de agris et pratis ad usum sacerdotis spectantibus.

Primo prestpold in Alsløff Engh circa tria plaustra.

Item in campo Bollerslo apud Heesthaw $^{2}$ ) I plaustrum.

Item ibidem in Lusech $^{3}$ ) I plaustrum I pratum IIII Thwyschare ${ }^{4}$ ) in latitudine.

Item IIII stuffagri circa Boldersle $\mathrm{Bro}^{5}$ ) in oriente circa dotem.

Item III holm in parte australi circa dotem ${ }^{6}$ ) cum uno prato confosso.
I det Herrens år 1443 var 24 sognemænd forsamlede i Bjolderup kirke for at træffe aftale om agre og enge, som skulle være til sognepræstens brug:

For det første Præstepold i Alslev eng omtrent 3 læs.

Endvidere i Bolderslev mark ved Hestehaverne 1 læs.

Endvidere sammesteds i Lyseg 1 læs og 1 eng, der var 4 dobbeltskær i bredden.

Endvidere 4 stufagre omkring Bolderslev Bro mod фst ved præstegården.

Endvidere 3 holme i den sydlige del ved præstegården sammen med en grøftet eng.

1) Vidnesbyrd herom er traditionen om $\emptyset$ nlev kirkes $\emptyset$ delæggelse (hos Niels Heldvad), Ønlev sogns opdeling, byen Søes' фdelæggelse (begge ifølge Slesvig bispens jordebog) og overleveringen om et slag ved Immervad (hos Arild Huitfeld efter adelig slægtebog).

2) Hestehaverne ligger $\varnothing$ st for Hærvejen i den nord $\varnothing$ stlige del af Bolderslev bymark ind imod skellet til Mellerup mark.

3) Kaldes i jordebogen fra 1704 Lüseeg og er da 》ein klein stück in Boldersleben holtzung « (Sdrj. Stednavne IV. 320). Forleddet tyder på et stednavn af sakralt indhold, muligvis har der her været et hedensk vi i tilslutning til Urnetinget (Sdrj. Månedsskrift 1949, 24-28 og 164). C. 1644 og 1704 og et par gange senere kaldes dette kirkestuf Noracker, hvilket er forsøgt tolket af Niortharakær (Sdrj. Mdsskr. 1951, 49-55).

4) »Tveskær«, dobbeltskær, et engmål. Engen kaldes nutildags Præsteeng.

5) Bolderslev Bro var i middelalderen betegnelsen på en drivvej umiddelbart $\varnothing$ st for Bjolderup kirke (muligvis med forbindelse til Frisvejen). Kirkeinventariet fra 1763, hvorfra disse oplysninger stammer, har formen »Boldersleber Pferdetrift«.

6) dos (ecclesiæ) er middelalderlatinsk betegnelse for præstegård (Sdrj. Arbøger 1946, 237 [Carsten Petersen]).

7) Peter Generani afskrift har formen Boldersleff. Ovenstående form er naturligvis en skriverfejl.

8) Her har vi nøglen til tydning af den nuværende form Randerstoft, som anføres i inventariet fra 1763; Sdrj. Stednavne IV. 322: »Forleddet er muligvis det jydske købstadnavn«, har således været en blindgyde. Forleddet »Randers «- forefindes først i det 18. århundrede. 
Item westen up Bayllerslo ${ }^{7}$ ) Marck Rawenstoft ${ }^{8}$ ) IIII agri.

Item I otting agger up Goskiær marck, dimidium ad usum sacerdotis, dimidium ad sustentationem Ecclesiæ.

Item up Wolderup marck ostert up Hawenberry III agri ad usum sacerdotis.

Item Rawenhy ${ }^{9}$ ) in oriente IIII orte landt.

Item in campo Rawid II agri in occidente parte Woldorp way.

Item in occidente circa Woldorp way II plaustra I pratum ad usum sacerdotis.

Item I agrum quem dedit Magnus Nielss in occidente circa Woldorp way ad usum sacerdotis.

Item I agrum in oriente circa cemiterium $^{10}$ ) et I agrum in occidente parte cemiterij.

Item II agri in aquilonari parte cemiterij ad usurn sacerdotis.

Item I pratum in oriente parte circa Rawit stock ${ }^{11}$ ) ad usum sacerdotis.

- Hæc præcedentia ex veteri originali transcripta sunt a Johanne Generano præposito Apenradensi.

Anno Dni 1614. 16. Mártij.
Endvidere vesten på Bolderslev mark Randerstoft 4 agre.

Endvidere 1 otting ager på Gåskær mark, halvdelen til sognepræstens brug, halvdelen til kirkens underhold.

Endvidere på Vollerup mark $\emptyset$ ster på Havnbjerg 3 agre til sognepræstens brug.

Endvidere (sammesteds) ${ }^{\circ}$ imod фst Ranghøj 4 ørtug land.

Endvidere i Raved mark 2 agre $i$ den vestlige del af Vollerup vad.

Endvidere (sammesteds) i vest omkring Vollerup vad 2 læs og 1 eng til sognepræstens brug.

Endvidere (sammesteds) 1 ager, som Magnus Nielsen har givet i vest omkring Vollerup vad til sognepræstens brug.

Endvidere 1 ager i фst omkring kirkegården og 1 ager i den vestlige del af kirkegården.

Endvidere 2 agre $i$ den nordlige del af kirkegården til sognepræstens brug.

Endvidere 1 eng i den $\varnothing$ stlige del omkring Ravedstok til sognepræstens brug.

Det ovenstående er afskrevet efter en gammel original af Johannes Generanus, provst i Åbenrå.

I det Herrens år 1614 den 16. marts.

Ovenstående fortegnelse over kirkeeje i Bjolderup sogn er bevaret $i$ to kopier fra 1600-tallet, af hvilke den ældste er taget af Åbenrå-provsten Johs. Generanus, som har dateret den til den 16. marts 1614. Den anden kopi indgår som led i et bredere

9) Trykt kirkeinventarium 1871 har Nørreranghøj og Sønderranghøj. Sdrj. Stednavne IV. 348 har formen Ronghøj.

10) Middelalderlatinsk betegnelse for kirkegård. Smlgn. fr. cimetière.

11) Mangler i Sdrj. Stednavne. Store og lille Stok er nutildags engdrag midtvejs mellem Bjolderup og Raved. 
anlagt kirkeinventarium med oplysninger om kirkens og præstens økonomiske forhold. Dette inventarium er udateret, men kan tidsfæstes til tiden mellem 1640 og 1656, idet amtmand Joachim Danckwerth i Åbenrå omtales som kammermester i Gottorp, hvad han blev i november 1640, og endvidere nævnes Bolderslev fogderis ridefoged Hans Asmussen, der sad inde med sin værdighed, indtil han ved et skøde udstedt på Ris herredsting den 2. december 1656 afhændede frigården i Bolderslev til sin søn Hieronymus Hansen (Bundesen) ${ }^{12}$ ). Da der forekommer aktuelle oplysninger fra året 1643 , er det sandsynligt, at denne kopi er affattet umiddelbart efter dette år, rimeligvis af den nye sognepræst Peter Generanus, der tiltrådte i 1644. Han var søn af den nys nævnte provst i Åbenrå; det må derfor antages, at den nye sjælesørger i Bjolderup har kendt sin fars afskrift fra 1614 .

Til slut i sin afskrift anfører Peter Generanus med rette, at de opremsede landerier meget vel ville have kunnet forsørge præsten, hvis de havde ligget samlet på et sted. I et trykt kirkeinventarium fra 1871 opgøres arealet da også tìl ikke mindre end ca. 40 demat ager og eng.

Forinden var dog noget af jorden gået tabi, idet bl. a. jordstykket ved Hestehaverne i det nuværende Bolderslevskov var blevet købt af ridefogeden i Bolderslev, uden at denne dog ifølge Peter Generani udsagn havde givet noget til vederlag herfor. De to stykker kirkestuf i den østlige del af Bolderslev mark indtager ved deres beliggenhed en særstilling blandt de jordstykker, der er omtalt i jordlisten fra 1443. Ingensinde har kirken i Bjolderup, der ligger en mils vej borte, kunnet få direkte okonomisk udbytte af disse jordstykker. ${ }^{13}$ )

12) LA. Haderslev amtsarkiv. Bolderslev distrikts rentekammersager. - Bundesen er slægtsnavnet. 1452 fik Jesse Bundessone frihed for Bolderslev frigård. 1673 kaldes Hieronymus Hansen (Bundesen) »arfsiddende«, vist en enestående oversættelse af det tyske »erbgesessen «. Smlgn. iøvrigt Bjolderup sogns historie (1951).

13) Se herom nærmere i Sdrj. Mdsskr. 1949, 24-28, 60 og 164 samt Bjolderup sogns historie (1951), hvor Urnehoved landsting og et hedensk vi henlægges til disse jordstykker. 
Til erstatning for det manglende præstebol fik præsten overladt et bol i Bolderslev. Ifølge den gamle nu tabte Bjolderup kirkebog fra 1594 havde „kongen i 1548 begunstiget hr. Johan Iversen, kirkeherre til Bjolderup, med den toft i Bolderslev, som hr. Hartich Stolte hidindtil havde besiddet dær" . ${ }^{14}$ ) Hartvig Stolte må antages at være Johan Iversens katolske forgænger i embedet. I begyndelse af 1600-tallet omtales den daværende sognepræst Marcus Johansen, en sønnesøn af Johan Iversen, som ejer af gården, der nu benævntes „H. Marci boel“. Efter hans død fæstede hans søn Johannes Marcellus den i 1644, idet Peter Generanus ikke fandt det lønnende at drive landbrug $i$ de tider. Engang i slutningen af århundredet - vel sagtens i uårene under og efter svenskekrigene - blev gården, der nu kaldes Bondesbol, knyttet sammen med Bolderslev frigård, hvorfra den først blev solgt i 1800 . -

Indtægterne fra de spredt liggende landerier var dog ingenlunde Bjolderup-præsternes eneste økonomiske grundlag. Rigelige tiendeafgifter og accidenser gjorde Bjolderup sognekald særdeles velaflagt, så det i økonomisk henseende fuldt ud kunne måle sig med andre nordslesvigske præsteembeder på landet.

14) Plattysk kirkebogsuddrag i Bjolderup kirkeinventarium fra 1763, jf. Peter Generani kirkeinventarium fra c. $1644 \mathrm{og}$ Bjolderup kirkeregnskabsbog 1595-1656 (LA). 